\title{
A CASE OF FETAL HETEROTAXY SYNDROME
}

\author{
Seung Joo Chon, MD', Suk Young Kim, MD', Soon Pyo Lee, MD', Byoung Cheoul Hwang, MD', Dong Woo Son, \\ $M D^{2}$, Chang Hyu Choi, $\mathrm{MD}^{3}$ \\ Departments of ${ }^{1}$ Obstetrics and Gynecology, ${ }^{2}$ Pediatrics, ${ }^{3}$ Cardiothoracic Surgery, Gil Hospital, Graduate School of Medicine, Gachon University of Medicine and \\ Science, Incheon, Korea
}

\begin{abstract}
Heterotaxy syndrome is a disorder that results in abnormal placement of organs. We report the prenatal diagnosis of complex cardiac abnormalities associated with left isomerism. A 32-year-old multigravida was referred to our hospital for evaluation of abnormal sonographic findings. On prenatal sonography, we suspected a double outlet of the right ventricle, right ventricular hypertrophy, a ventricular septal defect, a large azygos vein instead of an inferior vena cava, a right-sided stomach, and asplenia. Postnatal imaging studies confirmed these findings, except a left-sided single spleen. After birth, the infant underwent a left modified Blalock-Taussing shunt and underwent a 2nd surgical procedure (Kawashima operation, right pulmonary artery angioplasty, and atrial septal defect widening). This report suggests intrauterine fetal sonography can accurately delineate abnormal findings in heterotaxy, allowing perinatal counseling and postpartum planning for corrective surgery.
\end{abstract}

Keywords: Cavopulmonary shunt; Double outlet right ventricle; Heterotaxy; Isomerism; Prenatal ultrasonography

Heterotaxy is defined as an abnormal arrangement of viscera across the left-right axis [1,2]. Heterotaxy syndrome, cardiosplenic syndrome, right and left isomerism, and situs ambiguous are synonyms for these defects [3]. In addition to these anomalies, it is usual to find complex malformations within a heart, often requiring cardiac surgery during the neonatal period [4]. There can also be associated extracardiac anomalies which require early surgical intervention, such as biliary atresia and bowel obstruction [5]. Situs ambiguous is manifested as asplenia (right isomerism) or polysplenia (left isomerism), and is defined as cardiosplenic syndrome [6]. Left isomerism or right isomerism is diagnosed in $0.4-2 \%$ of all infants with congenital heart disease, but account for at least $6 \%$ of the cardiac defects detected in utero [7]. Numerous reports on heterotaxy syndrome have been published, but few studies describe the prenatal diagnosis of transposition-like double-outlet of the right ventricle (DORV) with ventricular septal defect (VSD), co-existing with an anomalous shaped of a right-sided single spleen. We report the prenatal diagnosis of complex cardiac abnormalities associated with heterotaxy with a brief review of the literature.

\section{Case Report}

A 32-year-old gravida 2 para 1 was referred to our hospital from a private clinic for fetal echocardiography at $33+3$ weeks gestational age. She was referred because of abnormal cardiac sonographic findings. Based on sonography, the fetus had a rightsided stomach (Fig. 1) opposite to the heart, presenting heterotaxy. On the 4-chamber view, fetal echocardiography showed the right ventricle (RV) to be larger than the left ventricle in a ratio of $1.62 \mathrm{~cm}: 0.63 \mathrm{~cm}$ (Fig. 2). There was also a $0.48 \mathrm{~cm}$ defect in the ventricular septum in the sub-pulmonic area and the ascending aorta and the pulmonary artery (PA) arose from the right ventricle, nearly side-by-side, clearly demonstrating DORV (PA: aorta [Ao] = diameter $1.08 \mathrm{~cm}: 0.59 \mathrm{~cm}$ ) (Fig. 3). Also, the sagittal oblique view

Received: 2011. 7.11. Accepted: 2011. 8.10.

Corresponding author: Suk Young Kim, MD

Department of Obstetrics and Gynecology, Gil Hospital, Graduate School of Medicine, Gachon University of Medicine and Science,

1198 Guwol-dong, Namdong-gu, Incheon 405-760, Korea

Tel: +82-1577-2299 Fax: +82-32-460-3290

E-mail: ksyob@gilhospital.com

This is an Open Access article distributed under the terms of the Creative Commons Attribution Non-Commercial License (http://creativecommons.org/licenses/ by-nc/3.0/) which permits unrestricted non-commercial use, distribution, and reproduction in any medium, provided the original work is properly cited.

Copyright $\odot$ 2011. Korean Society of Obstetrics and Gynecology 


\section{KOREAN JOURNAL OF OBSTETRICS \& GYNECOLOGY}

Seung Joo Chon, et al. A case of fetal heterotaxy syndrome

showed a large azygos vein placed posterior to the aorta (Fig. 4). On repeated sonography 1 week later, the same findings were noted with a narrowed aortic arch with poor visualization of the inominate vessels, and a spleen was not visible.

The patient was regularly followed and underwent repeat cesarean section at 38+5 weeks gestational age. The baby weighted 3,460 $\mathrm{g}$ with apgar scores of 6 at 1 minute and 9 at 5 minutes. Postnatal echocardiography, thoracic computed tomography aortography,

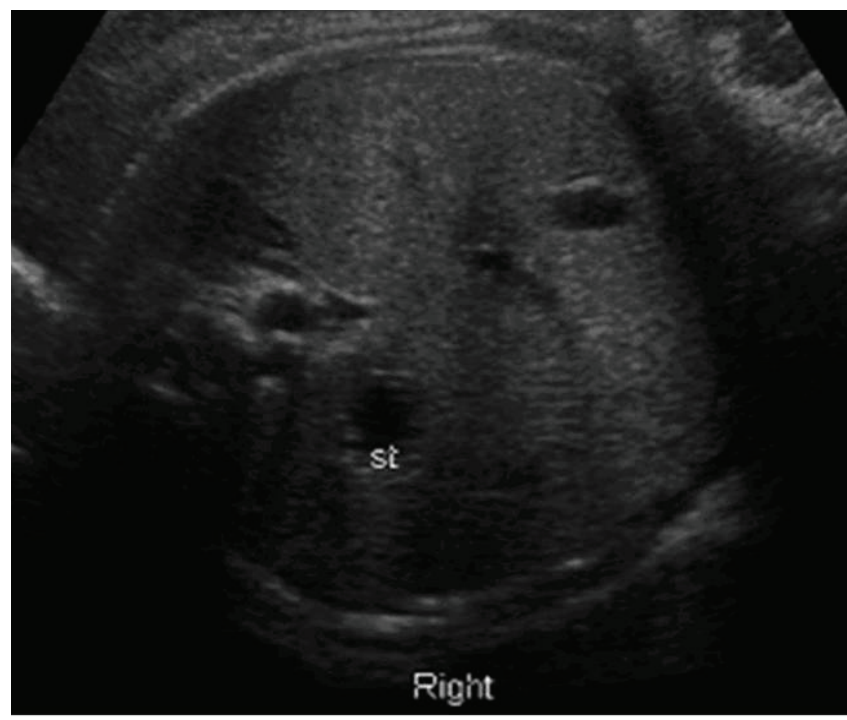

Fig. 1. Prenatal sonography showed abnormal findings. A right-sided stomach. st, stomach.

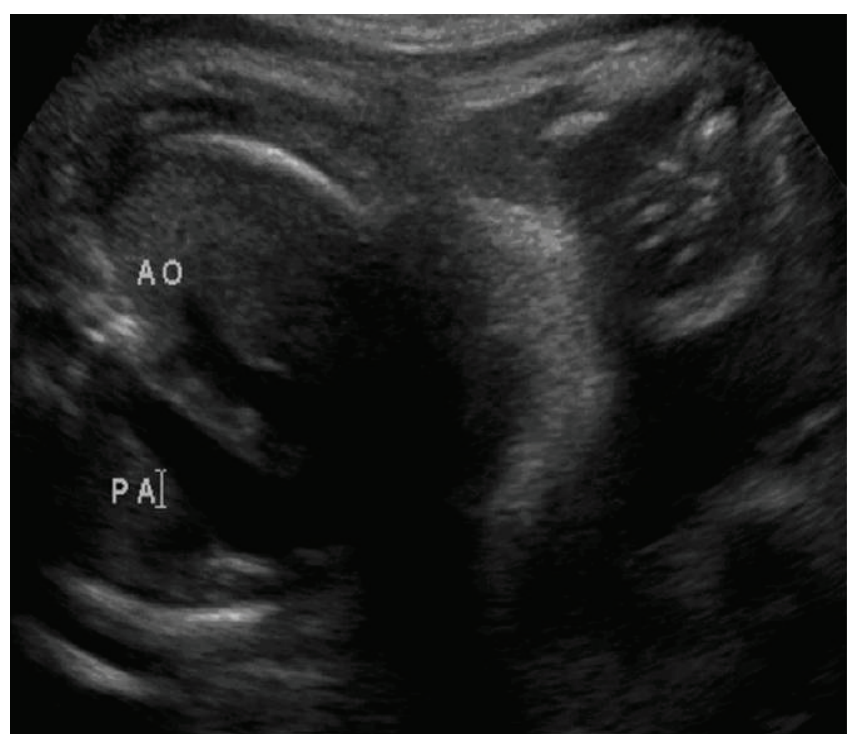

Fig. 3. Prenatal sonography showed abnormal findings. Double outlets of right ventricle pulmonary artery [PA]:aorta $[\mathrm{AO}]=$ diameter $1.08 \mathrm{~cm}: 0.59 \mathrm{~cm}$ ). and abdominal sonography confirmed the prenatal findings with a right-sided spleen additionally. Under the impression of DORV, at the age of 9 days, the infant underwent a left modified BlalockTaussing (LMBT) shunt in order to shunt some of the systemic circulation into the pulmonary circulation. On post-operative day 9, oxygen saturation was not adequate, thus extracorporeal membrane oxygenation (ECMO) was inserted and both lungs were treated for 2 additional days. As the condition improved, ECMO

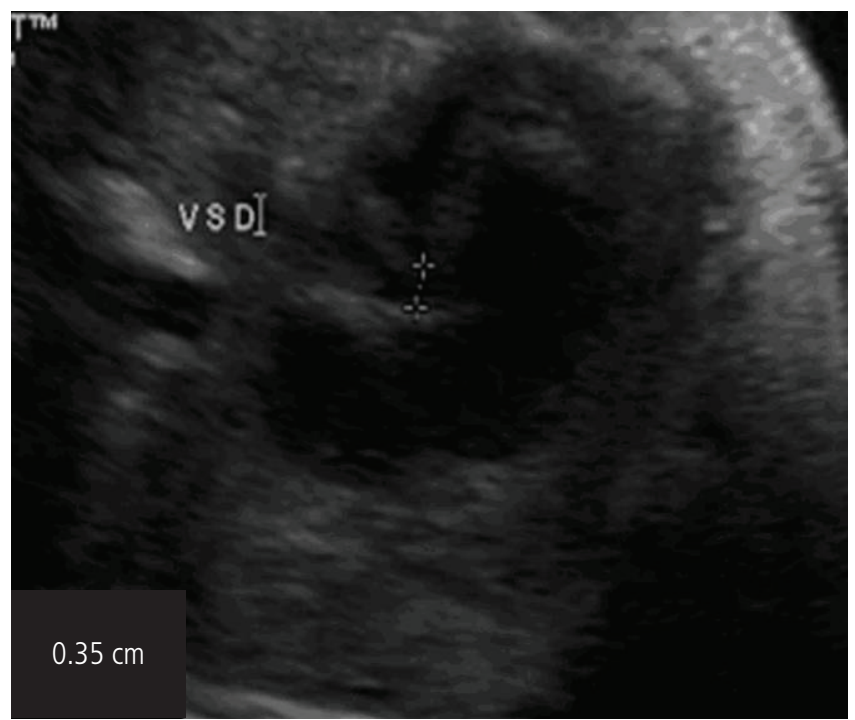

Fig. 2. Prenatal sonography showed abnormal findings. Right ventricle larger than left ventricle in a ratio of $1.62 \mathrm{~cm}: 0.63 \mathrm{~cm}$ with ventricular septal defect. VSD, ventricular septal defect.

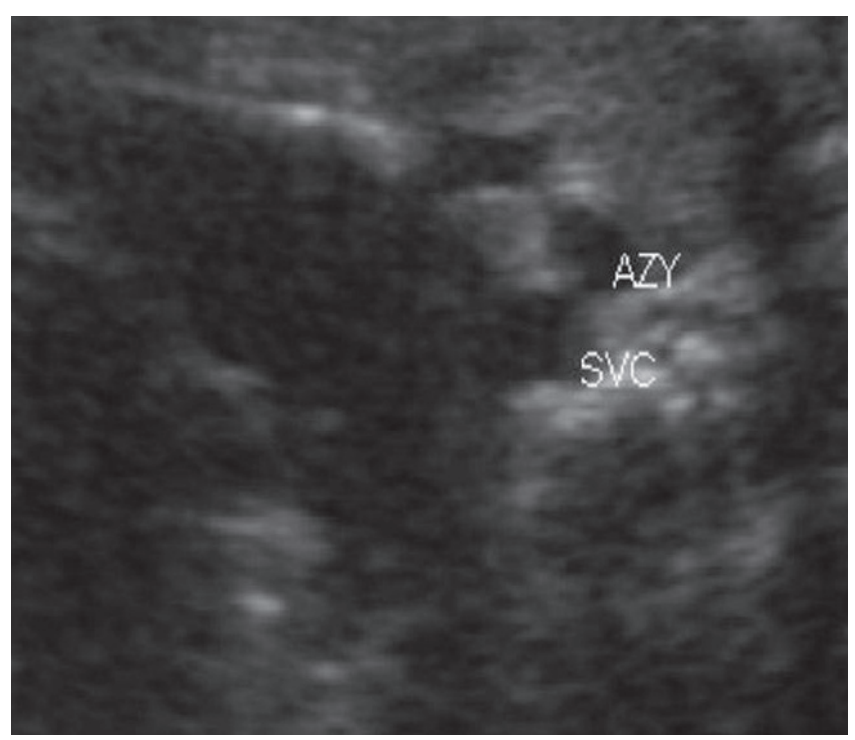

Fig. 4. Prenatal sonography showed abnormal findings. A large azygos vein placed posterior to the aorta. AZY, azygous vein; SVC, superior vena caval. 


\title{
KOREAN JOURNAL OF OBSTETRICS \& GYNECOLOGY
}

\author{
KJOG Vol. 54, No. 10, 2011
}

weaning was performed and the baby was discharged. After 8 months, the baby was shown to have progressive hypoxia, he underwent a Kawashima procedure (total cavopulmonary shunt), right pulmonary artery (RPA) angioplasty, and atrial septal defect widening under the impression of a narrowed LMBT shunt and RPA stenosis. On post-operative day 15 , the baby was shown to have a RV ejection fraction of $61 \%$ with adequate RV contraction without systemic flow disturbance that he was discharged home and was to be followed up regularly to the Cardiothoracic Department.

\section{Discussion}

Congenital heart disease, with a prevalence of 8 per 1,000 live births, is the most common severe congenital abnormality [8]. Second trimester routine ultrasound evaluation of the fetal heart has been proposed for prenatal detection of cardiac anomalies [9]. Fetal identification of congenital heart disease provides a unique opportunity to detect and observe congenital heart lesions with the stability that the fetal circulation provides [10]. Heterotaxy is almost always associated with asplenia or polysplenia [11]. Heterotaxy with asplenia is characterized by an asymmetric liver extending from one side of the abdomen to the other, with a stomach placed on either side, and the inferior vena cava (IVC), abdominal aorta being juxtaposed on the same side of the spine [11]. On the other hand, in most cases of heterotaxy with polysplenia, the liver has an asymmetric contour with one side being larger than the other, and IVC shows interruption to its suprarenal-infrahepatic segment, connected to the azygos or hemiazygos vein to drain into the superior vena cava [11]. The use of fetal echocardiography to diagnose congenital cardiac malformations prenatally is rapidly becoming the standard of care in most large pediatric cardiology centers [12].

In our case, like many others, heterotaxy syndrome was first suspected upon ultrasound identification of abnormal positions of fetal abdominal organs. The prenatal diagnosis of heterotaxy, in which the stomach placed on the right side, at the opposite side of the heart, was shown with complex cardiac malformations. Along with these abnormalities, the spleen was not visible on prenatal sonography initially, which later, after the birth, was found at right side of the body. Although several cases of DORV related to heterotaxy syndrome have been reported in the literature, this case represents a rare report of intrauterine diagnosis of DORV with an association to a single anomalous-shaped spleen being placed at right side, with a large liver covering upper abdomen with one functional single ventricle.

In summary, heterotaxy syndrome can be associated with numerous cardiac anomalies. In this case, the main cardiac abnormalities were both an ascending aorta with a right pulmonary trunk arising from the right ventricle with one functional single ventricle with VSD. This report suggests that intrauterine fetal echocardiography can accurately delineate the cardiac and vascular anatomy in heterotaxy, allowing planning prenatal counseling and postpartum planning for corrective surgery.

\section{References}

1. Bowers PN, Brueckner M, Yost HJ. The genetics of left-right development and heterotaxia. Semin Perinatol 1996;20:577-88.

2. Lin $A E$, Ticho BS, Houde $K$, Westgate MN, Holmes LB. Heterotaxy: associated conditions and hospital-based prevalence in newborns. Genet Med 2000;2:157-72.

3. Berg C, Geipel A, Smrcek J, Krapp M, Germer U, Kohl T, et al. Prenatal diagnosis of cardiosplenic syndromes: a 10-year experience. Ultrasound Obstet Gynecol 2003;22:451-9.

4. Cohen MS, Anderson RH, Cohen MI, Atz AM, Fogel M, Gruber $\mathrm{PJ}$, et al. Controversies, genetics, diagnostic assessment, and outcomes relating to the heterotaxy syndrome. Cardiol Young 2007;17 Suppl 2:29-43.

5. Taketazu M, Lougheed J, Yoo SJ, Lim JS, Hornberger LK. Spectrum of cardiovascular disease, accuracy of diagnosis, and outcome in fetal heterotaxy syndrome. Am J Cardiol 2006;97:720-4.

6. Tongsong T, Sittiwangkul R, Wanapirak C, Sirichotiyakul S. Prenatal diagnosis of transposition-like double-outlet right ventricle with mitral valve atresia in heterotaxy syndrome. J Clin Ultrasound 2005;33:197-200.

7. Lim JS, McCrindle BW, Smallhorn JF, Golding F, Caldarone CA, Taketazu M, et al. Clinical features, management, and outcome of children with fetal and postnatal diagnoses of isomerism syndromes. Circulation 2005;112:2454-61.

8. Stumpflen I, Stumpflen A, Wimmer M, Bernaschek G. Effect of detailed fetal echocardiography as part of routine prenatal ultrasonographic screening on detection of congenital heart disease. Lancet 1996;348:854-7.

9. Buskens E, Grobbee DE, Frohn-Mulder IM, Stewart PA, Juttmann RE, Wladimiroff JW, et al. Efficacy of routine fetal ultrasound screening for congenital heart disease in normal 


\section{KOREAN JOURNAL OF OBSTETRICS \& GYNECOLOGY}

Seung Joo Chon, et al. A case of fetal heterotaxy syndrome

pregnancy. Circulation 1996;94:67-72.

10. Cohen MS. Clarifying anatomical complexity: diagnosing heterotaxy syndrome in the fetus. Prog Pediatr Cardiol 2006;22:61-70.

11. Yoo SJ, Jaeggi E. Ultrasound evaluation of the fetal heart. In: Callen PW, editor. Ultrasonography in obstetetrics and gynecology, 5th ed. Philadelphia (PA): Saunders Elsevier; 2008. p.523-8.

12. Montaña E, Khoury MJ, Cragan JD, Sharma S, Dhar P, Fyfe D. Trends and outcomes after prenatal diagnosis of congenital cardiac malformations by fetal echocardiography in a well defined birth population, Atlanta, Georgia, 1990-1994. J Am Coll Cardiol 1996;28:1805-9.

\section{태아 장기역위증증후군의 1 예}

\section{가천의과학대학교 길병원 ${ }^{1}$ 산부인과학교실, ${ }^{2}$ 소아과학교실, ${ }^{3}$ 흉부외과학교실}

전승주 ${ }^{1}$, 김석영 ${ }^{1}$, 이순표 ${ }^{1}$, 황병철 ${ }^{1}$, 손동우 $^{2}$, 최창휴 $^{3}$

장기역위증이란 몸 속에 있는 장기들이 정상적인 위치가 아닌 다른 곳에 위치하고 있는 것을 말한다. 우리는 산전진찰에 좌심방 이성체 와 함께 비정상적인 심장 기형을 진단하게 된 1예를 보고하고자 한다. 32살의 경산모는 산전초음파상 이상 소견을 보인다는 주소로 지역 병원에서 본원 외래로 전원되었다. 산전진찰 초음파상 양대혈관우심실기시, 우심실비대, 심실중격결손증, 하대정맥 대신 커져있는 홑정맥, 우측에 위치한 위, 무비증이 의심되었다. 출생 후 시행한 영상학적인 검사들을 바탕으로 좌측에 위치한 단일 비장을 제외한 위의 소견들이 다시 한번 확인되었다. 출생 후, 유아는 체폐단락수술을 시행받았고, 수술 8개월후 수술 부위의 협착, 우측 폐동맥 협착증으로 인하여 두 번째 수술(가와시마수술, 우측폐동맥 혈관성형술, 심방중격결손확장술)을 시행받았다. 이 보고는 산전초음파로 장기전위증을 강력하게 의 심할 수 있었으며, 이것이 환아의 분만 전 치료계획 설립과 함께 분만 후 필요한 수술을 진행하는데 큰 도움이 되고 있다고 언급하고자 하 는 바이다.

중심단어: 체폐 단락, 양대혈관우심실기시, 장기전위증, 좌심방 이성체, 산전초음파 